\title{
Asociación de la temperatura superficial del mar y la abundancia del Piquero Café (Sula leucogaster) según el estado de desarrollo en el Parque Nacional Natural Gorgona
}

\section{Association of Sea Surface Temperature and the abundance of the Brown Booby (Sula leucogaster) according to the state of development in the Gorgona National Natural Park}

\author{
Alejandro Perlaza-Gamboa ${ }^{l *}$, Alan Giraldo ${ }^{l, 2}$, Luis Fernando Payán $^{3}$ y Felipe A. Estela ${ }^{4}$ \\ $\begin{array}{llll}\text { (iD } 0000-0003-0351-7905 & \text { (D) } 0000-0001-9182-888 \mathrm{X} & \text { (D) } 0000-0003-2326-6533 & \text { (iD) } 0000-0003-2090-1386\end{array}$
}

\begin{abstract}
1. Departamento de Biología, Facultad de Ciencias Naturales y Exactas, Universidad del Valle. alejandro.perlaza@correounivalle.edu.co, ecologia. animal@correounivalle.edu.co

2. Instituto de Investigaciones en Ciencias del Mar y Limnología (Incimar), Universidad del Valle, Cali, Colombia. alan.giraldo@correounivalle.edu.co

3. Estación Científica Henry von Prahl, Parque Nacional Natural Gorgona, Parques Nacionales Naturales de Colombia, Cali, Colombia. estacioncientificagorgona@gmail.com

4. Departamento de Ciencias Naturales y Matemáticas, Pontificia Universidad Javeriana, Cali, Colombia. felipe.estela@javerianacali.edu.co

* Autor de correspondencia
\end{abstract}

\section{RESUMEN}

$\mathrm{L}$ a variación de las condiciones fisicoquímicas del mar puede influir en la distribución y la abundancia de las aves marinas al afectar la estructura trófica del ambiente pelágico. Por ello se pretendió evaluar la asociación entre la abundancia de tres estados de desarrollo (pollos, juveniles y adultos) del Piquero Café (Sula leucogaster etesiaca) y la variación de la temperatura superficial del mar (TSM) y su anomalía térmica (ANOM) en isla Gorgona, Pacífico colombiano. Estas tendencias fueron evaluadas por medio de correlaciones cruzadas y modelos lineales generalizados. En cada estado de desarrollo la abundancia presentó una tendencia diferente ante la variación de la TSM o ANOM. Se sugiere que dichas tendencias se deben a que el incremento de la temperatura del mar podría estar asociado con una menor abundancia y disponibilidad de recursos presa. Bajo estas condiciones, los adultos tienden a disminuir el esfuerzo invertido en el cuidado parental e, incluso, reducen el suministro de alimento a juveniles dependientes y pollos para aumentar su propia supervivencia. Es posible que estas tendencias hayan estado asociadas con un régimen reproductivo que les permita a los volantones alcanzar la independencia de los padres durante el periodo con mayor disponibilidad de alimento.

PALABRAS CLAVE: desfase temporal, presas, piquero café, supervivencia, temperatura superficial del mar

\section{ABSTRACT}

$\mathrm{V}$ ariation in the physicochemical conditions of the sea can influence the distribution and abundance of seabirds by affecting the trophic structure of the pelagic environment. For this reason, we aimed to evaluate the association between the abundance of three developmental stages (chicks, juveniles, and adults) of the Brown Booby (Sula leucogaster etesiaca) and the sea surface temperature (SST) and its thermal anomaly (ANOM) in Gorgona Island, Colombian Pacific. These trends were assessed by performing cross-correlations and generalized linear models. Each developmental stage showed a different abundance tendence linked to SST and ANOM variation. It is suggested that these trends are due to the fact that increased sea temperature may be associated with reduced abundance and availability of prey resources. Under these conditions, adults tend to decreased the effort invested in parental care and even reduce the food supply to dependent juveniles and chicks to increase their own survival. These trends may have been associated with a breeding regime that allows fledglings to achieve independence from parents during the period of greatest availability of prey.

KEYWORDS: time delay, prey, Brown Bobby, survival, sea surface temperature

DOI: https://doi.org/10.25268/bimc.invemar.2020.49.SuplEsp.1046

Publicado por INVEMAR

Este es un manuscrito de acceso abierto bajo la licencia CC

Published by INVEMAR

Reconocimiento-No Comercial-Compartir Igual 


\section{INTRODUCCIÓN}

Los esfuerzos continuos de monitoreo de aves marinas permiten, entre otras cosas, relacionar tendencias poblacionales con la variación en las condiciones oceanográficas (Gaston et al., 2009; Grémillet y Boulinier, 2009; Humphries, 2015). Por ejemplo, ha sido establecido que los cambios en las condiciones de la temperatura superficial del mar (TSM) pueden afectar la reproducción y supervivencia de las aves marinas, al cambiar la estructura trófica del ambiente pelágico por la alteración en la disponibilidad y calidad alimenticia de sus presas (Schreiber, 2002; Frederiksen et al., 2006; Tompkins et al., 2017; Champagnon et al., 2018). Sin embargo, la respuesta a los cambios climáticos parece estar relacionada con la localidad, especie, sexo y estado de desarrollo (Anderson, 1989; Maness y Anderson, 2013; Champagnon et al., 2018). Por ejemplo, la supervivencia de los juveniles del Piquero de Patas Azules (Sula nebouxii) se reduce durante la fase cálida del ENSO (El Niño-Oscilación del Sur) (Oro et al., 2010), mientras que el número de individuos inmaduros del Albatros de Ceja Negra (Thalassarche melanophris) se incrementa al aumentar la TSM (Pardo et al., 2017).

En el Parque Nacional Natural Gorgona (PNNG) se ha estado desarrollando el programa de monitoreo de aves marinas más longevo de Colombia, iniciado en 2002 (Estela et al., 2010). Durante este monitoreo se ha registrado continuamente información de presencia, abundancia y estado reproductivo sobre cuatro especies de aves marinas recurrentemente avistadas en el PNNG (suliformes y pelecaniformes) (Cadena-López y Naranjo, 2010; PerlazaGamboa et al., 2020). Entre ellas se encuentra el Piquero Café (Sula leucogaster etesiaca), subespecie endémica del Pacífico tropical húmedo americano (Ospina-Álvarez, 2004), residente en la isla Gorgona, donde se ubica la mayor población con una colonia de aproximadamente 300 individuos y 100 parejas reproductivas (Cadena-López y Naranjo, 2010; Estela et al., 2016). Esta subespecie es considerada como en amenaza en el país (Renjifo et al., 2016).

Considerando que la variabilidad de las condiciones oceanográficas asociadas al PNNG son influenciadas por el ENSO (Blanco, 2009) y que este ha sido identificado como un factor relevante para la supervivencia y los aspectos reproductivos de otras especies de piqueros en el Pacífico Oriental Tropical (Anderson, 1989; Ribic et al., 1992; Mauck y Grubb, 1995; Ancona et al., 2012) y en isla Gorgona (Perlaza-Gamboa et al., 2020), en esta investigación se evalúa

\section{INTRODUCTION}

Continuous seabird monitoring efforts allow, among other things, to relate population trends to variation in oceanographic conditions (Gaston et al., 2009; Grémillet and Boulinier, 2009; Humphries, 2015). For example, it has been established that changes in the conditions of sea surface temperature (SST) can affect the reproduction and survival of seabirds, by changing the trophic structure of the pelagic environment, due to the alteration in food availability and quality of their prey (Schreiber, 2002; Frederiksen et al., 2006; Tompkins et al., 2017; Champagnon et al., 2018). However, the response to climate change appears to be related to locality, species, sex, and developmental stage (Anderson, 1989; Maness and Anderson, 2013; Champagnon et al., 2018). For example, the survival of juveniles of the Blue-footed Booby (Sula nebouxii) is reduced during the warm phase of the ENSO (El NiñoSouthern Oscillation) (Oro et al., 2010), while the number of immature individuals of the Black-browed Albatross (Thalassarche melanophris) increases with increasing SST (Pardo et al., 2017).

The Gorgona National Natural Park (GNNP) has been developing the longest-running seabird monitoring program in Colombia, started in 2002 (Estela et al., 2010). During this monitoring, information on the presence, abundance, and reproductive status of four species of seabirds recurrently sighted in the GNNP (Suliformes and Pelecaniformes) has been continuously recorded (CadenaLópez and Naranjo, 2010; Perlaza-Gamboa et al., 2020). Among them is the Brown Booby (Sula leucogaster etesiaca), an endemic subspecies of the American humid tropical Pacific (Ospina-Álvarez, 2004), resident on Gorgona Island where the largest population is located with a colony of approximately 300 individuals and 100 reproductive pairs (Cadena-López and Naranjo, 2010; Estela et al., 2016). This subspecies is considered as threatened in the country (Renjifo et al., 2016).

Considering that the variability of oceanographic conditions associated with GNNP are influenced by ENSO (Blanco, 2009) and this has been identified as a relevant factor for the survival and reproductive aspects of other booby species in the Eastern Tropical Pacific (Anderson, 1989; Ribic et al., 1992; Mauck and Grubb, 1995; Ancona et al., 2012) and on Gorgona Island (Perlaza-Gamboa et al., 2020), we evaluate the temporal dynamics of the Brown Booby colony in this locality, in order to answer 
la dinámica temporal de la colonia del Piquero Café en esta localidad con el propósito de responder la siguiente pregunta de investigación: ¿afecta la temperatura superficial del mar la variación temporal de la abundancia de los diferentes estados de desarrollo del Piquero Café (Sula leucogaster etesiaca) en isla Gorgona? Para ello, se parte del análisis de los registros de la abundancia de adultos, juveniles y pollos de esta especie realizados durante los monitoreos de aves marinas en el PNNG desde el 2002 hasta el 2018, así como de las condiciones de temperatura superficial del mar (TSM) y anomalía térmica (ANOM) en esta localidad.

\section{ÁREA DE ESTUDIO}

Dentro del área de conservación delimitada para el Parque Nacional Natural Gorgona (PNNG), se encuentran las islas Gorgona y Gorgonilla $\left(2^{\circ} 55^{\prime} 45^{\prime \prime}-3^{\circ} 00^{\prime} 55^{\prime \prime} \mathrm{N}\right.$ y $78^{\circ}$ $\left.09^{\prime} 00^{\prime \prime}-78^{\circ} 14^{\prime} 30^{\prime \prime} \mathrm{W}\right)$, ubicadas aproximadamente a 30 $\mathrm{km}$ del continente (Diaz et al., 2001; Giraldo et al., 2014a). En el extremo norte de Gorgona y alrededor de Gorgonilla se encuentran una serie de islotes y promontorios rocosos emergidos, en los cuales el Piquero Café construye sus nidos (Ospina-Álvarez, 2004; Cadena-López y Naranjo, 2010). Estos islotes presentan formas e inclinaciones variables. Los piqueros son capaces de anidar en terrenos con pendientes menores a $10^{\circ}$ y hasta de $90^{\circ}$ (Ospina-Álvarez, 2004). Los islotes pueden presentar alguna cobertura vegetal, principalmente de herbáceas, aunque los sitios de anidación pueden establecerse en partes del islote desprovistas de vegetación, a una altura promedio de 8,9 m.s.n.m. (OspinaÁlvarez, 2004).

La marea es de tipo semidiurno, con un rango de altura entre 4 y 5 m (Díaz et al., 2001; IDEAM, 2019). Se registran niveles de precipitación mayores a $6000 \mathrm{~mm} / \mathrm{año}$, con mayores registros entre mayo y noviembre y menores desde diciembre hasta abril (Blanco, 2009). Con relación a las características de la columna de agua del ambiente pelágico, se ha reportado un periodo frío de alta salinidad entre enero y abril, durante el cual la termoclina se ubica a 7 $\mathrm{m}$ de profundidad, $\mathrm{y}$ un periodo cálido de baja salinidad entre mayo y diciembre, durante el cual la termoclina se ubica a más de $40 \mathrm{~m}$ de profundidad (Giraldo et al., 2008).

\section{MATERIALES Y MÉTODOS}

La información utilizada para esta investigación correspondió a los registros mensuales de abundancia de Piquero Café realizados por funcionarios entrenados del the following research question "Does the sea surface temperature affect the temporal variation in the abundance of the different development stages of the Brown Booby (Sula leucogaster etesiaca) on the Gorgona Island?". To do this, we start with the analysis of the records of the abundance of adults, juveniles and chicks of this species carried out during the monitoring of seabirds in the GNNP from 2002 to 2018, as well as the sea surface temperature (SST) and thermal anomaly (ANOM) in this locality.

\section{STUDY AREA}

Within the delimited conservation area for the Gorgona National Natural Park (GNNP), are the Gorgona and Gorgonilla islands $\left(2^{\circ} 55^{\prime} 45^{\prime \prime}-3^{\circ} 00^{\prime} 55^{\prime \prime} \mathrm{N}\right.$ and $78^{\circ}$ $\left.09^{\prime} 00^{\prime \prime}-78^{\circ} 14^{\prime} 30^{\prime \prime} \mathrm{W}\right)$, located approximately $30 \mathrm{~km}$ from the continent (Diaz et al., 2001; Giraldo et al., 2014a). In the extreme north of Gorgona and around Gorgonilla there are a series of emerged rocky islets and promontories, in which the Brown Booby builds its nests (Ospina-Álvarez, 2004; Cadena-López and Naranjo, 2010). These islets have variable shapes and inclinations. The boobies are capable of nesting on land with slopes of less than $10^{\circ}$ and up to $90^{\circ}$ (Ospina-Álvarez, 2004). The islets may present some vegetation cover, mainly herbaceous, although the nesting sites can be established in parts of the islet devoid of vegetation at an average height of 8.9 m.a.s.l. (OspinaÁlvarez, 2004).

The tide is semi-diurnal, with a height range between 4 and $5 \mathrm{~m}$ (Diaz et al., 2001; IDEAM, 2019). Precipitation levels greater than $6000 \mathrm{~mm} /$ year are recorded, with higher records between May and November and lower from December to April (Blanco, 2009). Regarding the characteristics of the water column of the pelagic environment, a cold period of high salinity has been reported between January and April, during which the thermocline is located at $7 \mathrm{~m}$ depth, and a warm period of low salinity between May and December, during which the thermocline is more than $40 \mathrm{~m}$ deep (Giraldo et al., 2008).

\section{MATERIALS AND METHODS}

The information used for this research corresponded to the monthly abundance records of Brown Booby carried out by trained officials of the GNNP, between 2002 and 2018, through visual censuses along a predetermined route within the framework of the seabird monitoring program. of this protected area (Figure 1). These records are made 
PNNG, entre 2002 y 2018, mediante censos visuales a lo largo de un trayecto predeterminado en el marco del programa de monitoreo de aves marinas de esta área protegida (Figura 1). Estos registros se realizan durante dos días consecutivos de la primera semana de cada mes. Información detallada sobre la metodología asociada a este programa de monitoreo puede ser obtenida en Payán (2016) y Perlaza-Gamboa et al. (2020).

Cada individuo observado fue asignado a uno de tres estados de desarrollo definidos de acuerdo con las on two consecutive days of the first week of each month. Detailed information on the methodology associated with this monitoring program can be obtained in Payán (2016) and Perlaza-Gamboa et al. (2020).

Each individual observed was assigned to one of three stages of development defined according to the characteristics of their plumage: Chicks were identified by their characteristic white down, juveniles by presenting a general grayish-brown coloration with dark brown spots,

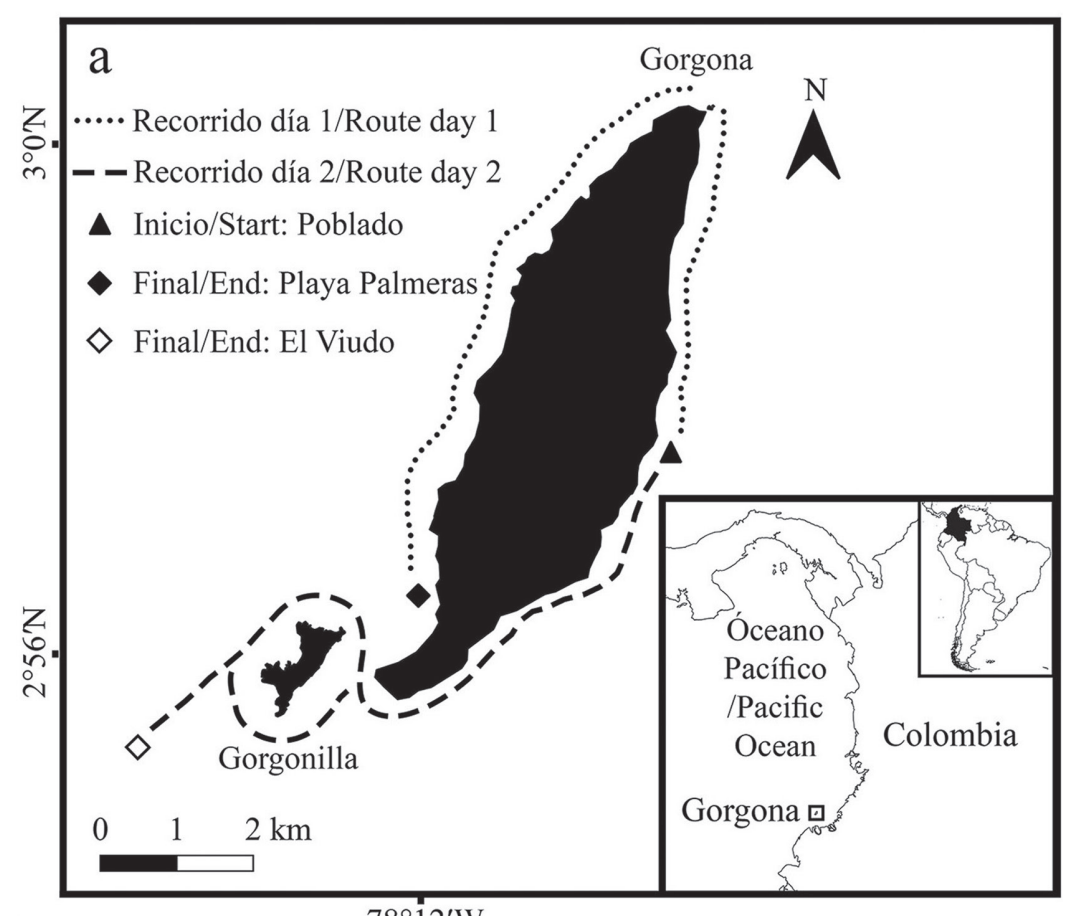

$78^{\circ} 12^{\prime} \mathrm{W}$

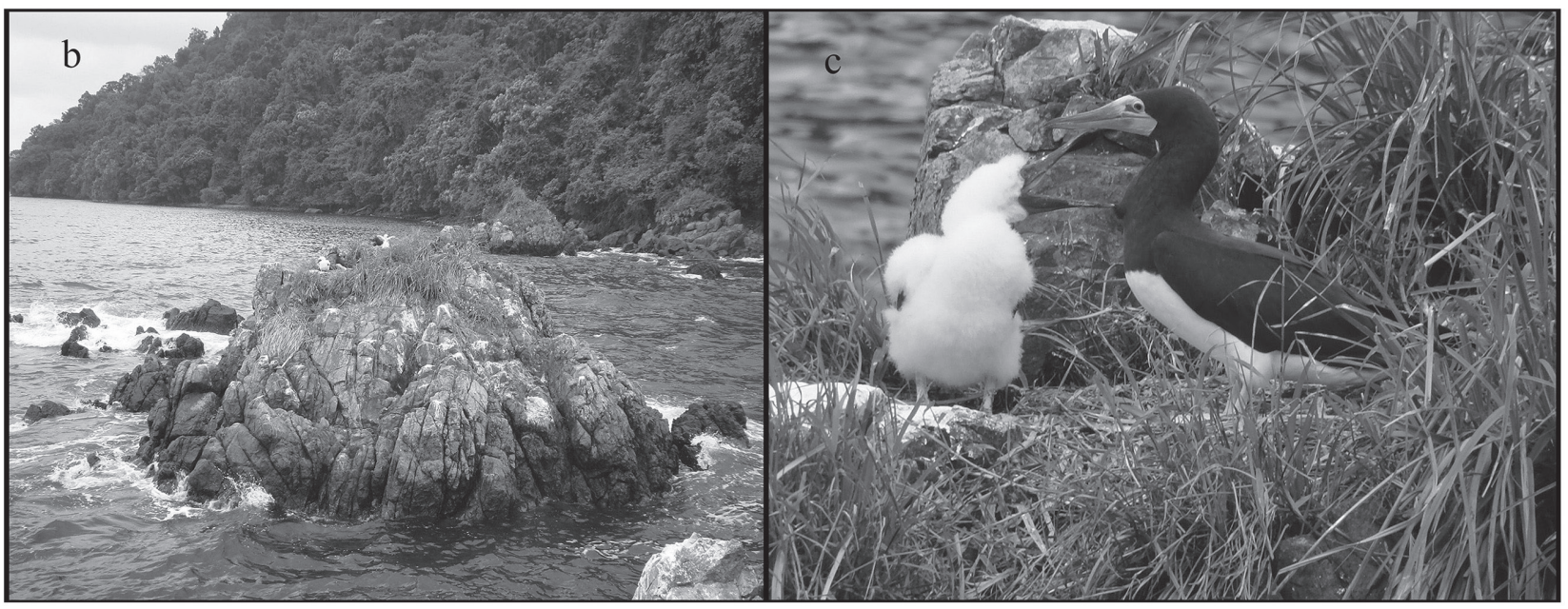

Figura 1. Generalidades del monitoreo de aves marinas del PNN Gorgona, Pacifico colombiano. A) Recorrido realizado durante el monitoreo. B) Ejemplo de islote en el sector norte de la Isla. C) Hembra y polluelo de Piquero Café (Sula leucogaster etesiaca). Fotografías: Felipe A. Estela.
Figure 1. Generalities of the monitoring of seabirds of the Gorgona NPN, Colombian Pacific. A) Route taken during the monitoring. B) Example of an islet in the northern sector of the Island. C) Female and chick of the Brown Booby (Sula leucogaster etesiaca). Photographs: Felipe A. Estela. 
características de su plumaje: los pollos se identificaron por su plumón blanco característico, los juveniles por presentar una coloración general café grisácea con motas café oscuro y los adultos por el contraste entre la coloración café oscura de la cabeza, cuello y dorso con el blanco del pecho bajo y vientre (Hilty y Brown, 2001; Ospina-Álvarez, 2004). Se estandarizaron las abundancias dividiendo el número de individuos observados por la distancia total recorrida en cada uno de los muestreos. Para dar uniformidad a los datos de abundancia, solo se consideraron para el análisis numérico los eventos de muestreo en los que se llevaron a cabo las dos jornadas de observación. Se utilizaron las abundancias de pollos registradas desde 2002, ya que su identificación fue siempre posible. Sin embargo, durante los primeros años de muestreo no se discernía entre individuos adultos y juveniles, por lo que para analizar estos dos estados de desarrollo se emplearon los datos obtenidos a partir de 2011, año desde el cual se empezó a diferenciar entre estas dos categorías. Los datos de individuos con estado de desarrollo no identificado no fueron utilizados. Para el análisis descriptivo de estos datos se utilizó la mediana como parámetro de tendencia central y la máxima y mínima abundancia como parámetros de dispersión para disminuir la influencia de datos atípicos y por tratarse de datos discretos.

Los datos de la TSM de isla Gorgona fueron obtenidos de las imágenes mensuales satelitales registradas por el sensor MODIS-Aqua del Ocean Biology Processing Group (OBPG), en la estación CPC16 de la malla de muestreo ERFEN ( $\left.3^{\circ} 0^{\prime} 0^{\prime \prime} \mathrm{N}-78^{\circ} 0^{\prime} 0^{\prime \prime} \mathrm{W}\right)$ (OBPG, 2015). La anomalía térmica (ANOM) fue calculada al substraer el promedio histórico mensual del periodo 2002-2018 de la serie temporal mensual de la TSM.

Para establecer el desfase temporal de la posible asociación entre la temperatura y abundancia de pollos, adultos y juveniles, se implementó una correlación cruzada entre los registros de la abundancia mensual con la TSM y la ANOM de isla Gorgona. El mayor desfase (Lag) permitido para los pollos fue de cuatro meses, puesto que es el lapso que incluye el periodo de incubación más el tiempo que tardan los pollos en crecer hasta ser visibles en el nido (Nelson, 1978; Ospina-Álvarez, 2004). Para los juveniles el mayor desfase permitido fue de siete meses, que corresponde, en promedio para la especie, al tiempo comprendido desde la incubación hasta la alimentación de volantones por parte de los padres (Nelson, 1978; Ospina-Álvarez, 2004). Finalmente, para los adultos el máximo desfase permitido fue de 12 meses, ya que este lapso abarca completamente la and adults by the contrast between the dark brown color of the head, neck, and back, with the white of the lower chest and belly (Hilty and Brown, 2001; Ospina-Álvarez, 2004). The abundances were standardized by dividing the number of individuals observed by the total distance traveled in each of the samplings. To give uniformity to the abundance data, only the sampling events in which the two observation days were carried out were considered for the numerical analysis. The chicken abundances recorded since 2002 were used since their identification was always possible. However, during the first years of sampling, it was not discerned between adult and juvenile individuals, so to analyze these two stages of development, the data obtained from 2011 were used, the year from which it began to differentiate between these two categories. Data from individuals with unidentified developmental status were not used. For the descriptive analysis of these data, the median was used as the central tendency parameter and the maximum and minimum abundance as dispersion parameters, to reduce the influence of atypical data and because they were discrete data.

The Gorgona Island SST data were obtained from the monthly satellite images recorded by the MODIS-Aqua sensor of the Ocean Biology Processing Group (OBPG), at the CPC16 station of the ERFEN sampling mesh $\left(3^{\circ} 0^{\prime}\right.$ $\left.0^{\prime \prime} \mathrm{N}-78^{\circ} 0^{\prime} 0^{\prime \prime} \mathrm{W}\right)$ (OBPG, 2015). The thermal anomaly (ANOM) was calculated by subtracting the monthly historical average for the period 2002-2018 from the monthly time series of the SST.

To establish the time lag of the possible association between temperature and the abundance of chicks, adults, and juveniles, a cross-correlation was implemented between the monthly abundance records with the SST and the ANOM of Gorgona Island. The greatest lag (Lag) allowed for chicks was four months since it is the period that includes the incubation period plus the time it takes for the chicks to grow until they are visible in the nest (Nelson, 1978; Ospina-Álvarez, 2004). For the juveniles, the greatest lag allowed was seven months, which corresponds, on average for the species, to the time from incubation to the feeding of fledglings by the parents (Nelson, 1978; Ospina-Álvarez, 2004). Finally, for adults, the maximum lag allowed was 12 months, since this period completely covers the variation in their abundance. The strength of the correlation was measured with the autocorrelation function (ACF), which for this study acquires a value of -1 for the highest negative correlation and 1 for the highest positive correlation. 
variación de su abundancia. La fuerza de la correlación fue medida con la función de autocorrelación (ACF) que, para este estudio, adquiere un valor de -1 en la mayor correlación negativa y de 1 para la mayor correlación positiva.

Se desarrolló un modelo lineal generalizado (MLG) para cada estado de desarrollo de manera independiente con la finalidad de explicar la posible relación entre la abundancia y la TSM y la ANOM, que presentaron correlaciones significativas teniendo en cuenta el desfase temporal encontrado en la correlación cruzada. Se utilizó la distribución quasipoisson porque se evaluaron datos de conteo y no se presentó sobredispersión. Los análisis y las figuras fueron hechos en el programa R (R Core Team, 2018). Se utilizó el paquete ggplot2 para las figuras (Wickham, 2016), astsa para la correlación cruzada (Stoffer, 2017) y MASS para los modelos (Venables y Ripley, 2002), además de otras funciones para organizar los datos (Wickham, 2007; Fox y Weisberg, 2011; Trapletti y Hornik, 2018).

\section{RESULTADOS}

Durante el periodo de estudio fueron hechos 184 registros mensuales de pollos de Piquero Café y 92 registros mensuales de adultos y juveniles. La abundancia de adultos presentó la mayor variación, con una mediana mensual de $5,70 \mathrm{ind} / \mathrm{km}$ y un máximo y mínimo de 11,02 y $2,00 \mathrm{ind} /$ $\mathrm{km}$, respectivamente. Los pollos presentaron una mediana mensual de $0,22 \mathrm{ind} / \mathrm{km}($ mínimo $=0 \mathrm{ind} / \mathrm{km}$ y máximo $=$ $2,62 \mathrm{ind} / \mathrm{km}$ ) y los juveniles de $0,42 \mathrm{ind} / \mathrm{km}$ (mínimo $=0$ ind $/ \mathrm{km}$ y máximo $=1,54 \mathrm{ind} / \mathrm{km}$ ), con mayores registros, en ambos casos, durante el último semestre (Figura 2).

La temperatura superficial del mar de isla Gorgona presentó una mediana igual a $27,26^{\circ} \mathrm{C}$, con registros entre $25,47{ }^{\circ} \mathrm{C}$ y $28,05{ }^{\circ} \mathrm{C}$. Los adultos no presentaron ninguna correlación significativa con la TSM ni con la ANOM. En contraste, la abundancia de juveniles presentó una correlación significativa con la ANOM y la TSM, con un desfase temporal de dos y un mes, respectivamente. Esto sugiere que el número de juveniles está asociado con la ANOM registrada dos meses antes y con la TSM del mes anterior. Finalmente, la abundancia de pollos estuvo correlacionada con la ANOM sin ningún desfase temporal y con la TSM registrada cuatro meses antes (Tabla 1).
A generalized linear model (GLM) was developed for each stage of development independently, to explain the possible relationship between abundance and SST and ANOM, that presented significant correlations, taking into account the time lag found in the cross-correlation. The quasipoisson distribution was used because count data were evaluated and there was no overdispersion. The analyzes and Figures were made in the R program (R Core Team, 2018). The ggplot2 package was used for the Figures (Wickham, 2016), astsa for the cross-correlation (Stoffer, 2017) and MASS for the models (Venables and Ripley, 2002), in addition to other functions to organize the data (Wickham, 2007; Fox and Weisberg, 2011; Trapletti and Hornik, 2018).

\section{RESULTS}

During the study period, 184 monthly records of Brown Booby chicks and 92 monthly records of adults and juveniles were made. The abundance of adults presented the greatest variation, with a monthly median of $5.70 \mathrm{ind} / \mathrm{km}$ and a maximum and minimum of 11.02 and $2.00 \mathrm{ind} / \mathrm{km}$ respectively. Chicks presented a monthly median of 0.22 ind $/ \mathrm{km}$ (minimum $=0 \mathrm{ind} / \mathrm{km}$ and maximum $=2.62 \mathrm{ind} /$ $\mathrm{km}$ ) and the juveniles $0.42 \mathrm{ind} / \mathrm{km}$ (minimum $=0 \mathrm{ind} / \mathrm{km}$ and maximum $=1.54 \mathrm{ind} / \mathrm{km}$ ), with higher records, in both cases, during the last semester (Figure 2).

The sea surface temperature of Gorgona Island presented a median equal to $27.26^{\circ} \mathrm{C}$, with records between $25.47{ }^{\circ} \mathrm{C}$ and $28.05{ }^{\circ} \mathrm{C}$. The adults did not present any significant correlation with SST or ANOM. In contrast, the abundance of juveniles showed a significant correlation with ANOM and SST, with a time lag of two and one months, respectively. This suggests that the number of juveniles is associated with the ANOM registered two months before and with the SST of the previous month. Finally, the abundance of chicks was correlated with the ANOM without any time lag, and with the SST reported four months earlier (Table 1). 


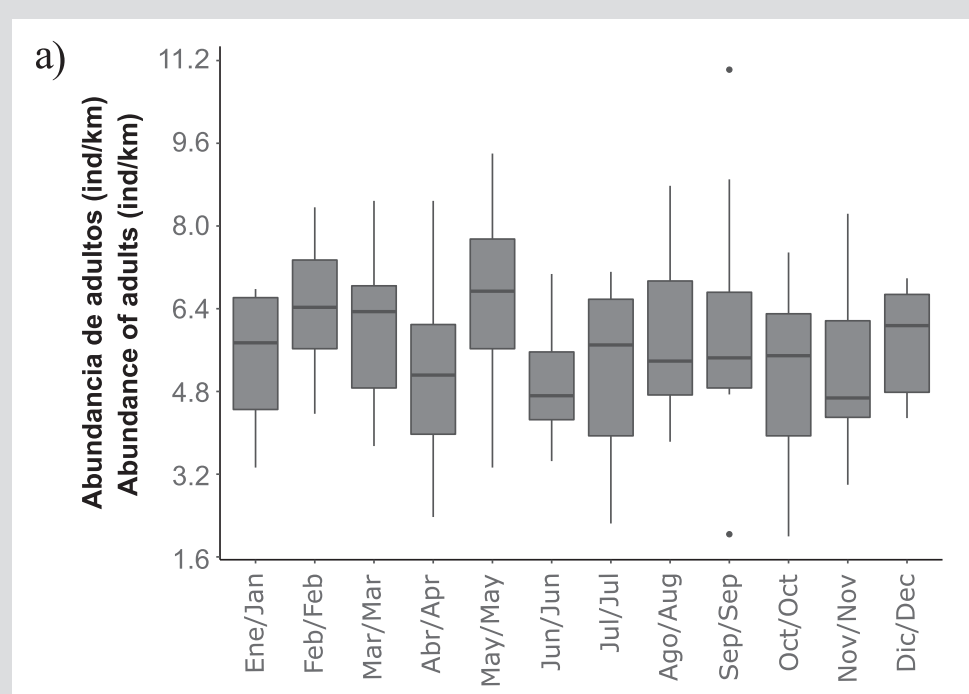

b)

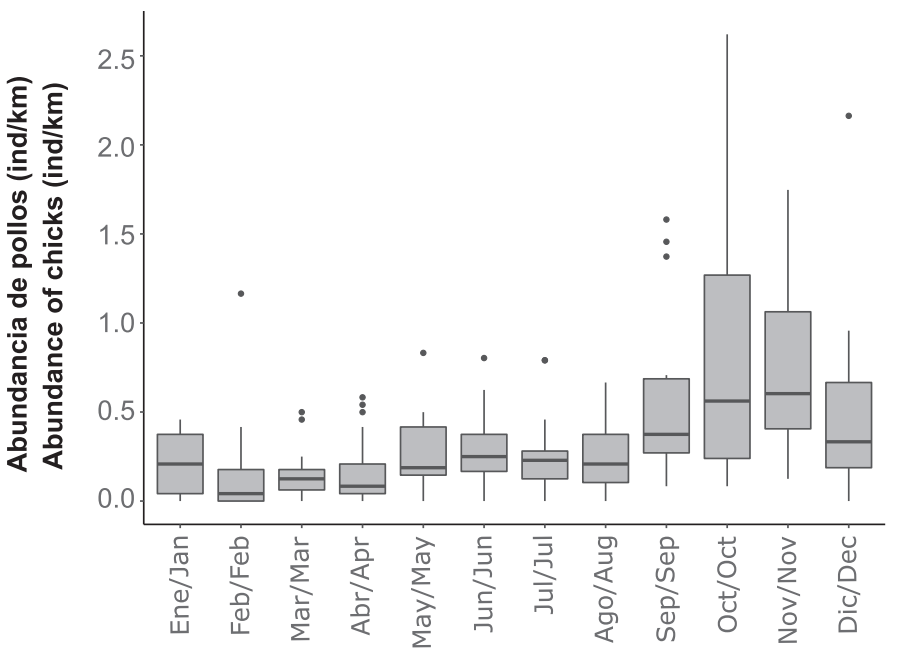

c)

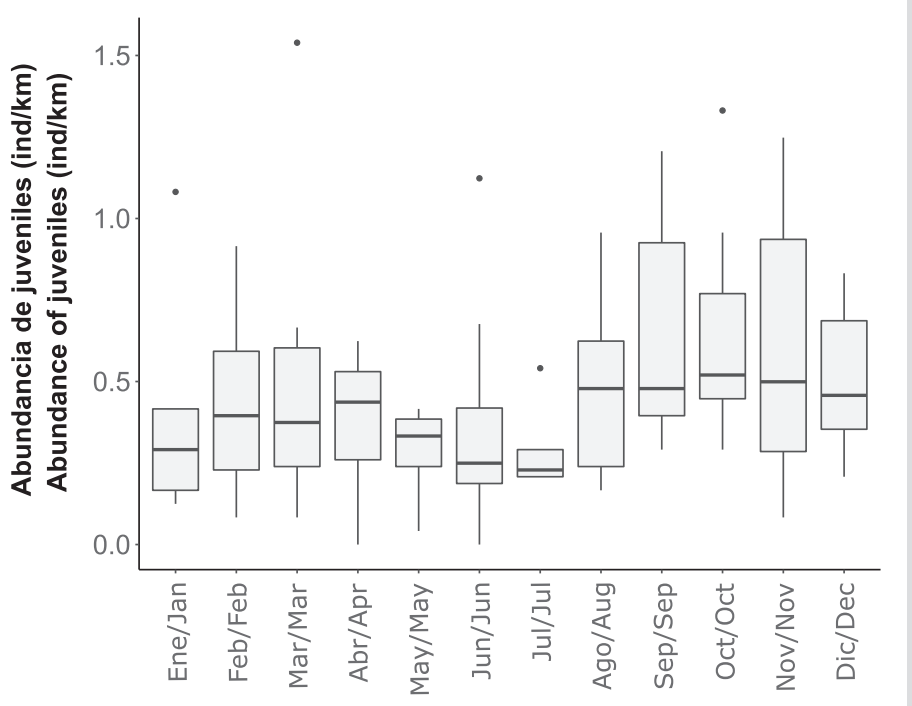

Figura 2. Variación mensual de la abundancia de A) adultos, B) pollos y C) juveniles de Piquero Café (Sula leucogaster etesiaca) en isla Gorgona, Pacífico colombiano. La caja representa la mediana y los percentiles de $25 \%$ y $75 \%$. Las barras representan el valor máximo y mínimo no atípico y los puntos corresponden a datos atípicos.
Figure 2. Monthly variation of the abundance of A) adults, B) chicks and C) juveniles of the Brown Booby (Sula leucogaster etesiaca) on Gorgona Island, Colombian Pacific. The box represents the median and $25 \%$ and $75 \%$ percentiles. The bars represent the non-outlier maximum and minimum value and the points correspond to outliers. 
Tabla 1. Correlación cruzada entre la abundancia mensual de pollos, juveniles y adultos de Piquero Café (Sula leucogaster etesiaca) con la temperatura superficial del mar (TSM) de isla Gorgona (Gor) y su anomalía térmica $(\mathrm{ANOM}) . \mathrm{ACF}=$ fuerza de correlación. $\mathrm{ANOM}=$ anomalía térmica. $\mathrm{Lag}=$ desfase temporal de la correlación medido en meses. NS = correlación no significativa.
Table 1. Cross-correlation between the monthly abundance of chicks, juveniles, and adults of the Brown Booby (Sula leucogaster etesiaca) with the sea surface temperature (SST) of Gorgona Island (Gor) and its thermal anomaly $(\mathrm{ANOM}) . \mathrm{ACF}=$ strength of correlation. $\mathrm{ANOM}=$ thermal anomaly. Lag = time lag of correlation measured in months. NS = nonsignificant correlation.

\begin{tabular}{|c|c|c|c|c|c|c|}
\cline { 2 - 7 } \multicolumn{1}{c|}{} & \multicolumn{2}{c|}{$\begin{array}{c}\text { Abundancia de pollos/ } \\
\text { Chicken abundance }\end{array}$} & \multicolumn{2}{c|}{$\begin{array}{c}\text { Abundancia de juveniles/ } \\
\text { Juvenile abundance }\end{array}$} & \multicolumn{2}{c|}{$\begin{array}{c}\text { Abundancia de adultos/ } \\
\text { Abundance of adults }\end{array}$} \\
\hline Temperaturas/Temperatures & ACF & Lag (meses/months) & ACF & Lag (meses/months) & ACF & Lag (meses/months) \\
\hline ANOM Gor & -0.171 & 0 & -0.372 & -2 & NS & NS \\
\hline TSM Gor & 0.294 & -4 & -0.335 & -1 & NS \\
\hline
\end{tabular}

De acuerdo con el modelo lineal generalizado (MLG) desarrollado entre la abundancia de juveniles con la ANOM (coeficiente $=0,33 ; \mathrm{P}<0,001$ ) y la TSM (coeficiente $=0,52 ; \mathrm{P}<0,001)$, considerando el respectivo desfase $(\mathrm{Lag})$, el número de juveniles tiende a disminuir con el incremento de ambas variables térmicas (Figura 3A y 3B). Por otro lado,
According to the generalized linear model (GLM) developed between the abundance of juveniles with the ANOM (coefficient $=0.33 ; \mathrm{P}<0.001$ ) and the SST (coefficient $=0.52 ; \mathrm{P}<0.001)$, considering the respective lag (Lag), the number of juveniles tends to decrease with the increase of both thermal variables (Figure 3A and 3B). On
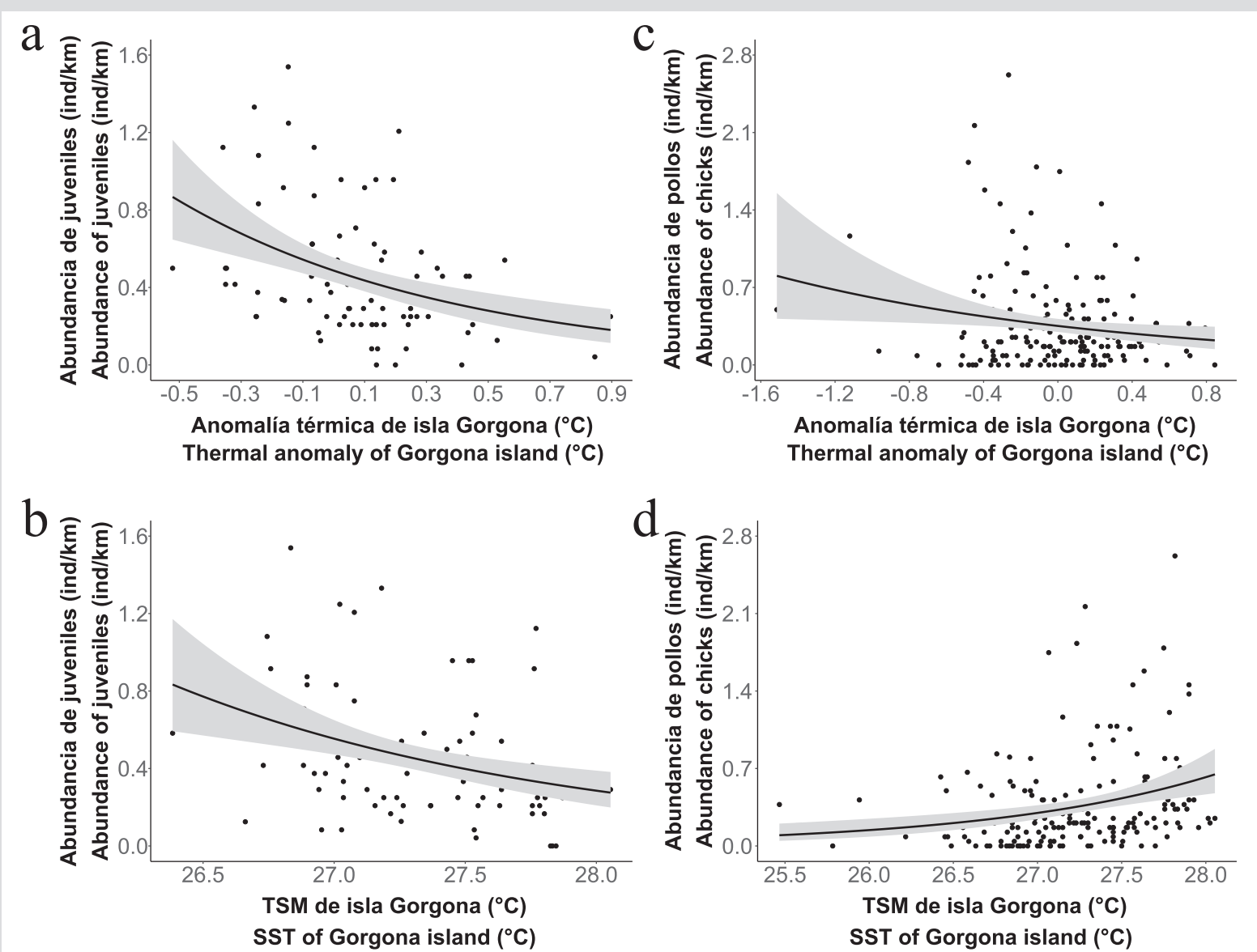

Figura 3. Relación de la abundancia de juveniles y pollos de Piquero Café (Sula leucogaster etesiaca) con la anomalía térmica (ANOM) (A y C) y la temperatura superficial del mar (TSM) (B y D) de isla Gorgona, Pacífico colombiano. El área sombrada representa el intervalo de confianza de $95 \%$.

Figure 3. Relationship of the abundance of juveniles and chicks of the Brown Booby (Sula leucogaster etesiaca) with the thermal anomaly (ANOM) (A and C) and the sea surface temperature (SST) (B and D) of Gorgona Island, Colombian Pacific. The shaded area represents the $95 \%$ confidence interval. 
la abundancia de pollos tiende a disminuir con el aumento de la ANOM (coeficiente $=0,58 ; \mathrm{P}=0,017$ ) (Figura 3C), pero incrementa al aumentar la TSM (coeficiente $=2,08 ; \mathrm{P}$ $<0,001$ ) (Figura 3D).

\section{DISCUSIÓN}

La abundancia de pollos y juveniles de Piquero Café asociadas a isla Gorgona fue mayor en los últimos meses del año, probablemente como consecuencia de la concentración del esfuerzo reproductivo entre julio y septiembre, condición que fue reportada por Cadena-López y Naranjo (2010). Sin embargo, esta especie exhibe actividad reproductiva durante todo el año, con una baja variación intraanual del tamaño de la población (Ospina-Álvarez, 2004; Cadena-López y Naranjo, 2010; Perlaza-Gamboa et al., 2020). En este régimen reproductivo la mayoría de las posturas ocurre entre junio y agosto, con un periodo de incubación entre 40 y 44 días, seguido de un lapso entre uno y tres meses en que los pollos crecen hasta ser visibles y adquieren el plumón blanco característico, que al final de este periodo empieza a mudar por el plumaje café (Nelson, 1978). Una vez estos individuos realizan el primer vuelo, aproximadamente a los 96 días de edad (Nelson, 1978; Ospina-Álvarez, 2004), son alimentados por los padres durante las siguientes tres a ocho semanas, aunque este periodo puede extenderse dependiendo de la disponibilidad de presas (Schreiber y Norton, 2002). Este sistema favorece que los individuos adquieran la independencia de los padres durante los primeros meses del año, tiempo en el cual se ha registrado mayor productividad en el ambiente pelágico aledaño a isla Gorgona (Giraldo et al., 2014b).

Esta estrategia reproductiva ha sido registrada para otras especies de aves marinas que comienzan a reproducirse cuando hay menor productividad en el ecosistema y sus presas están menos disponibles, pero permite que las crías alcancen la independencia de los padres cuando se presenta la mayor disponibilidad de presas (Passuni et al., 2016, 2018). Por lo general, esta estrategia es llevada a cabo, principalmente, por las aves cuyo alimento está ampliamente distribuido, como ocurre con las aves marinas (Nelson, 1978; Furness y Monaghan, 1987; Vilchis et al., 2006). Además, cabe mencionar que el desfase de cuatro meses en la correlación positiva entre la abundancia de pollos y la TSM sugiere que la mayor abundancia observada en octubre y noviembre se ve influenciada por las temperaturas registradas a mitad de año, tiempo en el que ocurre la transición entre el periodo de mayor a menor productividad the other hand, the abundance of chicks tends to decrease with the increase in ANOM (coefficient $=0.58 ; \mathrm{P}=0.017$ ) (Figure 3C), but increases with increasing SST (coefficient $=2.08 ; \mathrm{P}<0.001)($ Figure 3D).

\section{DISCUSSION}

The abundance of chicks and juveniles Brown Boobies associated with Gorgona Island was higher in the last months of the year, probably as a consequence of the concentration of reproductive effort between July and September, a condition that was reported by Cadena-López and Naranjo (2010). However, this species on Gorgona Island exhibits reproductive activity throughout the year, with a low intra-annual variation in population size (Ospina-Álvarez, 2004; Cadena-López and Naranjo, 2010; Perlaza-Gamboa et al., 2020). In this reproductive regime, egg laying mainly occurs between June and August, with an incubation period between 40 and 44 days, followed by a period between one and three months in which the chicks grow until they are visible and acquire the characteristic white down, that at the end of this period they begin to molt to a brown plumage (Nelson, 1978). Once these individuals make the first flight, at approximately 96 days of age (Nelson, 1978; Ospina-Álvarez, 2004), they are fed by the parents for the next three to eight weeks, although this period can be extended depending on prey availability (Schreiber and Norton, 2002). This system encourages individuals to acquire independence from their parents during the first months of the year, during which time greater productivity has been reported in the pelagic environment near Gorgona Island (Giraldo et al., 2014b).

This reproductive strategy has been reported for other species of seabirds, which begin to reproduce when there is less productivity in the ecosystem and their prey is less available, but it allows the juveniles to achieve independence from their parents when there is the greatest availability of prey. (Passuni et al., 2016, 2018). In general, this strategy is carried out, mainly, by birds whose food is widely distributed, such as seabirds (Nelson, 1978; Furness and Monaghan, 1987; Vilchis et al., 2006). In addition, it is worth mentioning that the four-month lag in the positive correlation between the abundance of chicks and the SST suggests that the greater abundance observed in October and November is influenced by the temperatures registered in the middle of the year, at which time the transition between the period of highest to lowest productivity occurs in the Eastern Tropical Pacific (Pennington et al., 2006) and 
en el Pacífico Oriental Tropical (Pennington et al., 2006) y probablemente en los alrededores de isla Gorgona (Giraldo et al., 2014b). Este patrón es similar al observado en el Pacífico tropical mexicano, donde el periodo reproductivo estuvo asociado principalmente con la época más cálida y menos productiva del año, pero coincide con el incremento de la disponibilidad de presas migratorias de aguas cálidas (Hernández-Vázquez et al., 2017). Por estas razones, para comprender el régimen reproductivo del Piquero Café en isla Gorgona, resulta necesario profundizar en el conocimiento sobre la variación poblacional intra anual de sus recursos presa, así como determinar el periodo en el que la mayoría de las crías adquiere la independencia de los padres.

Es probable que la menor productividad asociada con aguas más cálidas y mayor precipitación entre mayo y diciembre (Diaz et al., 2001; Giraldo et al., 2014b) provoque mayor pérdida de pollos, como ha sido registrado para otras aves marinas en el Pacífico Oriental (Jaksic y Fariña, 2010). Esto podría desencadenar con más frecuencia segundas nidadas por parte de las parejas reproductivas (Nelson, 1978) y resultar así en un mayor número de pollos observados en los últimos meses. Por otro lado, la correlación negativa encontrada entre la abundancia de pollos y la anomalía térmica sugiere que estos individuos son afectados por los cambios de la temperatura del mar, posiblemente por la disminución en el alimento brindado por sus padres. Por ejemplo, para algunas aves marinas se ha asociado el aumento de la temperatura del mar y la disminución en el éxito reproductivo con una alteración en la productividad del mar y la disponibilidad de presas (Ancona et al., 2011; Furness, 2016). La menor disponibilidad de recursos presa relacionada con aguas más cálidas puede explicar la disminución de la abundancia de juveniles del Piquero Café cuando aumenta la TSM y ANOM en el ambiente pelágico de isla Gorgona.

Durante condiciones adversas, como la baja disponibilidad de presas, algunas especies longevas como el Piquero Café (Hennicke et al., 2012) generalmente tienden a minimizar los costos individuales de la reproducción (Mauck y Grubb, 1995). Por ejemplo, los adultos disminuyen el esfuerzo invertido en el cuidado parental y en el suministro de alimento a los juveniles dependientes o pollos con la finalidad de incrementar su propia supervivencia, pero disminuyendo el éxito reproductivo (Maness y Anderson, 2013). Esta estrategia puede explicar por qué no se observó ninguna correlación significativa entre los adultos y la TSM o ANOM, pero sí en los pollos y juveniles. Además, probably in the surroundings of Gorgona Island (Giraldo et al., 2014b). This pattern is similar to that observed in the Mexican tropical Pacific, where the reproductive period was mainly associated with the warmest and least productive time of the year, but coincides with the increase in the availability of migratory warm-water prey (HernándezVázquez et al., 2017). For these reasons, to understand the reproductive regime of the Brown Booby on Gorgona Island, it is necessary to deepen the knowledge about the intra-annual population variation of its prey resources, as well as to determine the period in which most of the offspring acquire independence from parents.

It is likely that the lower productivity associated with warmer waters, and greater precipitation between May and December (Diaz et al., 2001; Giraldo et al., 2014b), causes greater loss of chicks, as has been reported for other seabirds in the Eastern Pacific (Jaksic and Fariña, 2010). This could trigger more frequent second clutches by reproductive pairs (Nelson, 1978), resulting in a greater number of chicks observed in recent months. On the other hand, the negative correlation found between the abundance of chicks and the thermal anomaly suggests that these individuals are affected by changes in sea temperature, possibly through the decrease in the food provided by their parents. For example, for some seabirds, increases in sea temperature and decreases in reproductive success have been associated with altered sea productivity and prey availability (Ancona et al., 2011; Furness, 2016). The lower availability of prey resources related to warmer waters may explain the decrease in the abundance of juvenile Brown Booby when SST and ANOM increase in the pelagic environment of Gorgona Island.

During adverse conditions, such as low prey availability, some long-lived species, such as the Brown Booby (Hennicke et al., 2012) generally tend to minimize individual costs of reproduction (Mauck and Grubb, 1995). For example, adults reduce the effort invested in parental care and the supply of food to dependent juveniles or chicks, to increase their survival, but decrease reproductive success (Maness and Anderson, 2013). This strategy may explain why no significant correlation was observed between adults and SST or ANOM, but it was observed in chicks and juveniles. Furthermore, the abundance of this booby described by Perlaza-Gamboa et al. (2020) could be mainly due to the decrease in the number of juveniles, possibly because the food supply was lower when the SST increased. However, this effect is likely less in species that have parental care before and after the chicks become fledglings 
la abundancia de este piquero descrita por Perlaza-Gamboa et al. (2020) podría deberse sobre todo a la disminución en el número de juveniles, posiblemente debido a que el suministro de alimento haya sido menor cuando aumentaba la TSM. No obstante, es probable que este efecto sea menor en las especies que presentan cuidado parental antes y después de que las crías se conviertan en volantones (Stienen y Brenninkmeijer, 2002; Maness y Anderson, 2013), como es el caso del Piquero Café (Ospina-Álvarez, 2004). Así y todo, estas hipótesis deben ser confirmadas por un estudio que evalúe las estrategias llevadas a cabo por los parentales durante condiciones de estrés y sus consecuencias en el desarrollo y la supervivencia de su descendencia antes y después de haber alcanzado la independencia.

\section{CONCLUSIONES}

La TSM y ANOM de isla Gorgona están asociados con las tendencias observadas en la variación poblacional de los pollos y juveniles de Piquero Café, posiblemente a través de un efecto sobre el suministro de peces pelágicos brindados por los padres, debido a que es probable que estos individuos no puedan satisfacer las necesidades de las crías, pero sí logren mantenerse vivos durante la época de escasez de alimento. Esto se evidencia en un menor número de juveniles y pollos durante los meses con mayores anomalías, lo que sugiere que la variación de la TSM y ANOM puede repercutir en la reproducción de esta población. Además, posiblemente, el régimen reproductivo garantiza que las crías alcancen la independencia de los padres cuando haya mayor disponibilidad de recursos presa.

\section{AGRADECIMIENTOS}

A Ximena Zorrilla y Héctor Chirimía del Parque Nacional Natural Gorgona (PNNG). A Julio César Herrera Carmona por su ayuda en la construcción de la serie temporal de la TSM y a Wilmar Alexander Torres por sus recomendaciones para el desarrollo de los análisis estadísticos. A WWF y a la Asociación Calidris por el apoyo en el programa de monitoreo de aves marinas desde sus inicios hasta ahora. Este trabajo de investigación fue cofinanciado por el PNNG, la Universidad del Valle y WWF-Colombia, y se realizó en el marco de un acuerdo de entendimiento entre el PNNG y el grupo de investigación en Ecología Animal de la Universidad del Valle. Publicación 008 del Instituto de Ciencias del Mar y Limnología (Incimar) de la Universidad del Valle.
(Stienen and Brenninkmeijer, 2002; Maness and Anderson, 2013), as is the case of the Brown Booby (Ospina-Álvarez, 2004). Nevertheless, these hypotheses must be confirmed by a study that evaluates the strategies carried out by parents during stressful conditions, and their consequences on the development and survival of their offspring before and after having achieved independence.

\section{CONCLUSIONS}

The SST and ANOM of Gorgona Island are associated with the trends observed in the population variation of chicks and juveniles of the Brown Booby, possibly through an effect on the supply of pelagic fish provided by the parents, since it is probable that these Individuals cannot meet the needs of the young, but they do manage to stay alive during times of food shortage. This is evidenced in a lower number of juveniles and chicks during the months with the greatest anomalies, which suggests that the variation in SST and ANOM may affect the reproduction of this population. Also, possibly the reproductive regime ensures that the young achieve independence from the parents when there is greater availability of prey resources.

\section{ACKNOWLEDGEMENTS}

To Ximena Zorrilla and Héctor Chirimía from the Gorgona National Natural Park (GNNP). To Julio César Herrera Carmona for his help in the construction of the SST time series and to Wilmar Alexander Torres for his recommendations for the development of statistical analyzes. To WWF and to the Calidris Association for supporting the seabird monitoring program from its inception until now. This research work was co-financed by the GNNP, the Universidad del Valle, and WWF-Colombia, and was carried out within the framework of an understanding agreement between the GNNP and the Animal Ecology research group of the Universidad del Valle. Publication 008 of the Institute of Marine Sciences and Limnology (Incimar) of Universidad del Valle. 


\section{BIBLIOGRAFÍA/LITERATURE CITED}

Ancona, S., S. Sánchez-Colón, C. Rodríguez, and H. Drummond. 2011. El Niño in the warm tropics: local sea temperature predicts breeding parameters and growth of blue-footed boobies. J. An. Ecol., 80: 799-808. https://doi.org/10.1111/j.1365-2656.2011.01821.x

Ancona, S., I. Calixto-Albarrán, and H. Drummond. 2012. Effect of El Niño on the diet of a specialist seabird, Sula nebouxii, in the warm eastern tropical Pacific. Mar. Ecol. Progr. Ser., 462: 261-271. https://doi.org/10.3354/meps09851

Anderson, D.J. 1989. Differential responses of boobies and other seabirds in the Galapagos to the 1986-87 El Nino-Southern Oscillation event. Mar. Ecol. Progr. Ser., 52: 209-2016.

Blanco, J.F. 2009. The hydroclimatology of Gorgona Island: seasonal and Enso-Rel. patterns. Actual. Biol., 31(91): 111-121.

Cadena-López, G. y L.G. Naranjo. 2010. Distribución, abundancia y reproducción de las aves marinas residentes en el Parque Nacional Natural Gorgona, Colombia. Bol. SAO, 20: 22-32.

Champagnon, J., J. D. Lebreton, H. Drummond, and D. J. Anderson. 2018. Pacific decadal and El Niño oscillations shape survival of a seabird. Ecology, 99(5): 1063-1072. https://doi.org/10.1002/ecy.2179

Díaz, J.M., J.H. Pinzón, A.M. Perdomo, L.M. Barrios y M. López-Victoria. 2001. Generalidades. 17-26. En Barrios, L.M. y M. Lopez-Victoria (Eds.), Gorgona marina: contribución al conocimiento de una isla única. Ser. Publ. Esp. Invemar, (7).

Estela, F.A., M. López Victoria, L.F. Castillo y L.G. Naranjo. 2010. Estado del conocimiento sobre aves marinas en Colombia después de 110 años de investigación. Bol. SAO, 20: 2-21.

Estela, F.A., G. Cadena y J. Lasso-Zapata. 2016. Sula leucogaster. 139-143. En Renjifo, L.M., Á. M. Amaya-Villarreal, J. Burbano-Girón y J. VelásquezTibatá (Eds.). Libro rojo de aves de Colombia. Volumen II: ecosistemas abiertos, secos, insulares, acuáticos continentales, marinos, tierras altas del Darién y Sierra Nevada de Santa Marta y bosques húmedos del centro, norte y oriente del país. Pont. Univ. Javeriana e Inst. Alexander von Humboldt, Bogotá. 563 p.

Fox, J. and S. Weisberg. 2011. An R Companion to Applied Regression [software]. Thousand Oaks: Sage. http://socserv.socsci.mcmaster.ca/jfox/Books/ Companion. 04/04/2019.

Frederiksen, M., M. Edwardst, A.J. Richardson, N.C. Halliday, and S. Wanless. 2006. From plankton to top predators: bottom-up control of a marine food web across four trophic levels. J. An. Ecol., 75(6): 1259-1268. https://doi.org/10.111 11/j.1365-2656.2006.01

Furness, R.W. 2016. Impacts and effects of ocean warming on seabirds. 271-288. En Laffoley, D. y J. M. Baxter (Eds.). Explaining ocean warming: causes, scale, effects and consequences. IUCN, Gland, Switzerland.

Furness, R.W. and P. Monaghan. 1987. Seabird ecology. Chapman \& Hall, New York.

Gaston, A.J., D.F. Bertram, A. W. Boyne, J.W. Chardine, G. Davoren, A.W. Diamond, A. Hedd, W.A. Montevecchi, J.M. Hipfner, M.J.F. Lemon, M.L. Mallory, J.F. Rail, and G.J. Robertson. 2009. Changes in Canadian seabird populations and ecology since 1970 in relation to changes in oceanography and food webs. Environ. Rev., 17: 267-286. https://doi.org/10.1139/A09-013

Giraldo, A., E. Rodríguez-Rubio y F. Zapata. 2008. Condiciones oceanográficas en isla Gorgona, Pacífico oriental tropical de Colombia. Latin Am. J. Aq. Res., 36(1): 121-128. https://doi.org/10.3856/vol36-issue1-fulltext-12

Giraldo, A., M.C. Díaz-Granados y C.F. Gutiérez-Landázuri. 2014a. Isla Gorgona, enclave estratégico para los esfuerzos de conservación en el Pacífico Oriental Tropical. Rev. Biol. Trop., 62: 1-12.

Giraldo, A., B. Valencia, J.D. Acevedo y M. Rivera. 2014b. Fitoplancton y zooplancton en el área marina protegida de Isla Gorgona, Colombia, y su relación con variables oceanográficas en estaciones lluviosa y seca. Rev. Biol. Trop., 62: 117-132.

Grémillet, D. and T. Boulinier. 2009. Spatial ecology and conservation of seabirds facing global climate change: a review. Mar. Ecol. Progr. Ser., 391(2): 121-137. https://doi.org/10.3354/meps08212

Hennicke, J.C., B. King, D. Drynan, L.J. Hardy, A. Stokes, and S. Taylor. 2012. New life-span records of the Brown Booby Sula leucogaster. Mar. Ornithol., 40(2), 125-126.

Hernández-Vázquez, S., E. Mellink, J.A. Castillo-Guerrero, R. Rodríguez-Estrella, J.Á. Hinojosa-Larios y V.H. Galván-Piña. 2017. Ecología reproductiva del bobo café (Sula leucogaster) en tres islas del Pacífico Tropical mexicano. Ornitol. Neotrop., 28: 57-66.

Hilty, S.L. y W.L. Brown. 2001. Guía de las aves de Colombia. Princeton, New Jersey. 1040 p.

Humphries, G.R.W. 2015. Estimating regions of oceanographic importance for seabirds using a-spatial data. PLoS ONE, 10(9): e0137241. https://doi. org/10.1371/journal.pone.0137241 
IDEAM. 2019. Pronóstico de pleamares y bajamares Costa Caribe colombiana 2020. Inst. Hidrol. Meteorol. Est. Amb., Bogotá. 135 p.

Jaksic, F.M. and J.M. Fariña. 2010. El Niño and the birds: a resource-based interpretation of climatic forcing in the southeastern Pacific. An. Inst. Patagonia, 38(1): 121-140. https://doi.org/10.4067/s0718-686x2010000100009

Maness, T.J. and D.J. Anderson. 2013. Predictors of juvenile survival in birds. Ornithol. Monogr., 78: 1-55. https://doi.org/10.1525/om.2013.78.1.1.

Mauck, R.A. and T.C. Grubb. 1995. Petrel parents shunt all experimentally increased reproductive costs to their offspring. An. Behav., 49: 999-1008. https:// doi.org/10.1006/anbe.1995.0129

Nelson, J.B. 1978. The Sulidae, gannets and boobies. Oxford University Press, Oxford. 1012 p.

OBPG. 2015. MODIS aqua level 3 SST thermal IR monthly 4km daytime v2014.0. https://podaac.jpl.nasa.gov/dataset/MODIS_AQUA_L3_SST_ THERMAL_MONTHLY_4KM_DAYTIME_V2014.0.21/01/2019.

Oro, D., R. Torres, C. Rodríguez, and H. Drummond. 2010. Climatic influence on demographic parameters of a tropical seabird varies with age and sex. Ecology, 91(4): 1205-1214.

Ospina-Álvarez, A. 2004. Ecología reproductiva y colonialidad del piquero café Sula leucogaster (Aves: Sulidae), en el PNN Gorgona, Pacífico colombiano. Tesis Biol., Univ. Valle, Cali. 116 p.

Pardo, D., S. Jenouvrier, H. Weimerskirch, and C. Barbraud. 2017. Effect of extreme sea surface temperature events on the demography of an age-structured albatross population. Phil. Trans. Royal Soc. B. Biol. Sci., 372: 20160. https://doi.org/10.1098/rstb.2016.0143

Passuni, G., C. Barbraud, A. Chaigneau, H. Demarcq, J. Ledesma, A. Bertrand, R. Castillo, A. Perea, J. Mori, V. A. Viblanc, J. Torres-Maita, and S. Bertrand. 2016. Seasonality in marine ecosystems: Peruvian seabirds, anchovy, and oceanographic conditions. Ecology, 97(1), 182-193. https://oi org/10.1890/14-1134.1

Passuni, G., C. Barbraud, A. Chaigneau, A. Bertrand, R. Oliveros-Ramos, J. Ledesma, R. Castillo, M. Bouchon, and S. Bertrand. 2018. Long-term changes in the breeding seasonality of Peruvian seabirds and regime shifts in the Northern Humboldt Current System. Mar. Ecol. Progr. Ser., 597: $231-242$. https://doi.org/https://doi.org/10.3354/meps 12590

Payan, L.F. 2016. Informe de monitoreo de aves marinas, Parque Nacional Natural Gorgona, Febrero - Diciembre 2016. Cali.

Pennington, J.T., K.L. Mahoney, V.S. Kuwahara, D.D. Kolber, R. Calienes, and F.P. Chavez. 2006. Primary production in the eastern tropical Pacific: a review. Progr. Oceanogr., 69(2-4): 285-317. https://doi.org/10.1016/j.pocean.2006.03.012

Perlaza-Gamboa, A., A. Giraldo, L.F. Payán y F.A. Estela. 2020. Variación poblacional de tres especies de piqueros (Suliformes: Sulidae) en isla Gorgona, Pacífico colombiano, según la temperatura del mar. Rev. Biol. Trop., 68(2): 704-713.

R Core Team. 2018. R: a language and environment for statistical computing (Version 3.5.2). R Foundation for Statistical Computing, Vienna. https://www.rproject.org. 04/04/2019.

Renjifo, L.M., Á.M. Amaya-Villarreal, J. Burbano-Girón y J. Velásquez-Tibatá (Eds). 2016. Libro rojo de aves de Colombia. Volumen II: Ecosistemas abiertos, secos, insulares, acuáticos continentales, marinos, tierras altas del Darién y Sierra Nevada de Santa Marta y bosques húmedos del centro, norte y oriente del país. Bogotá, D.C.: Editorial Pontificia Universidad Javeriana e Instituto Alexander von Humboldt.

Ribic, C.A., D.G. Ainley, and L.B. Spear. 1992. Effects of El Nino and La Nina on seabird assemblages in the equatorial Pacific. Mar. Ecol. Progr. Ser., 80: 109-124. https://doi.org/10.3354/meps080109

Schreiber, E.A. 2002. Climate and weather effects on seabirds: 179-216. En Schreiber, E.A. y J. Burger (Eds.). Biology of marine birds. CRC Press, Boca Ratón, USA.

Schreiber, E.A. and R.L. Norton. 2002. Brown Booby (Sula leucogaster), version 2.0. En Poole, A. y F.B. Gill (Eds.). The birds of North America online. Cornell Lab of Ornithology, Ithaca, USA. https://doi.org/10.2173/bna.649

Stienen, E.W.M. and A. Brenninkmeijer. 2002. Variation in growth in Sandwich Tern chicks Sterna sandvicensis and the consequences for pre- and postfledging mortality. Ibis, 144: 567-576. https://doi.org/10.1046/j.1474-919X.2002.00086.x

Stoffer, D. 2017. astsa: Applied Statistical Time Series Analysis [software]. https://cran.r-project.org/package=astsa. 04/04/2019.

Tompkins, E.M., H.M. Townsend, and D.J. Anderson. 2017. Decadal-scale variation in diet forecasts persistently poor breeding under ocean warming in a tropical seabird. PLoS ONE, 12(8): 1-24. https://doi.org/10.1371/journal.pone.0182545

Trapletti, A. and K. Hornik. 2018. tseries: Time Series Analysis and Computational Finance [software]. https://cran.r-project.org/package=tseries. 04/04/2019.

Venables, W.N. and B.D. Ripley. 2002. Modern applied statistics with S [software]. Springer, New York, USA. http://www.stats.ox.ac.uk/pub/MASS4. 04/04/2019. 
Vilchis, L.I., L.T. Balance, and P.C. Fiedler. 2006. Pelagic habitat of seabirds in the Eastern Tropical Pacific: effects of foraging ecology on habitat selection. Mar. Ecol. Progr. Ser., 315: 279-292. https://doi.org/10.3354/meps315279

Wickham, H. 2007. Reshaping data with the reshape package [software]. J. Statist. Softw., 21(12): 1-20. http://www.jstatsoft.org/v21/i12/. 04/04/2019.

Wickham, H. 2016. ggplot2: Elegant graphics for data analysis [software]. Springer-Verlag, New York. http://ggplot2.org. 04/04/2019.

RECIBIDO/RECEIVED: 23/07/2020 